\section{THE CENTENARIES OF GERHARDT AND WURTZ.}

$I^{T}$ is surely a coincidence not without its special significance that, at the very time when France, with the sympathy of the greater part of the civilised world, is nobly struggling to regain the provinces of which she was despoiled nearly half a century ago, it should be her pious duty and peculiar privilege to celebrate the centenaries of two of her many eminent sons, both illustrious in the annals of chemical science, both Alsatians, and Frenchmen to their very finger-tips. These events, occurring under present conditions, we may be sure, have not failed to impress the soul of France, or to stimulate and strengthen her resolution to gather again within her fold those compatriots of whom a brutal and arrogant despotism had ruthlessly robbed her. Subjects of which Gerhardt and Wurtz are types are, indeed, among the most precious of her assets. In thus commemorating the services of these distinguished Alsatians, the Chemical Society of France has also expressed the sentiments of admiration and esteem with which those services are regarded wherever science is appreciated.

Charles Frederic Gerhardt was born at Strasburg on August 21, 1816, and died in that city on August 19, 1856 . The son of a white-lead manufacturer at Hangenbieten, near Strasburg, it was the intention of his father that Gerhardt should assist him in his business, and with the object of learning chemistry he was sent, on leaving the Protestant gymnasium of his native place, first to the Polytechnic at Carlsruhe, and then to Leipzig, where he worked in Erdmann's laboratory. Here, when barely nineteen years of age, he made his first contribution to the literature of science-a lengthy paper in the Journal für Praktische Chemie on "The Formulæ of the Natural Silicates." He now returned to Hangenbieten, but the craft of chemical manufacturing had no attractions for him. He eventually threw up his position and enlisted in a cavalry regiment, from which, thanks to the generosity of Liebig, to whom he became in turn pupil, friend, and rival, he was enabled to procure his discharge. After a short stay at Giessen he made a second attempt to comply with his father's wishes. It was no more successful than the first, and, after eighteen months of irksome drudgery, he finally abandoned the effort and betook himself to Paris. Although only twenty-two, the venture was not altogether hopeless; for he had already made a mark in French scientific circles by his translation of Liebig,s "Introduction to the Study of Chemistry," published by Mathias in 1837 . The handsome, well-grown youth, almost feminine in features, was well received by Dumas, whose early experiences were not wholly dissimilar, and under his encouragement Gerhardt attached himself to the Répertoire de Chimie, then directed by
Gaultier re Claubry.

On its foundation, in 1840 , by Dr. Quesneville, Gerhardt joined the staff of the Revue Scientifique, NO. 253 I, VOI. IOI] and became one of the most active of the contributors to that famous periodical. The times were favourable to the development of his genius, and no field for the display of his peculiar talents could be better than that journal. Revolutions were impending not only in the political world, but also in that of science. It was, perhaps, the most pre-eminently polemical period in the history of chemistry - a time of Homeric combats between the opposing schools of France and Germany. Gerhardt, from his antecedents and upbringing, was well fitted to be what he actually became-a free-lance, whose keen and incisive thrusts were directed, with equal impartiality, sometimes at one protagonist and sometimes at the other. No wonder that the articles over the signature " $\mathrm{Z}$ " were eagerly scanned by both sets of combatants.

Space will not permit of any detailed examination of Gerhardt's powers as a critic. One example, however, may be given, which, although of minor importance, is typical of his skill in sarcasm. As is well known to chemists interested in the history of their science, the followers of Liebig were at first disposed to scoff at the doctrine of substitution, and the editor of the Annalen had disfigured his pages by a letter, supposed to emanate from Paris, and signed S. C. H. Windler, in which the writer, in execrable French, attempted a reductio ad absurdum of Dumas's great discovery. It was a somewhat clumsy piece of buffoonery, flavoured with that spice of malice which so frequently characterises what Germans regard as humour. Gerhardt took a neat revenge by reprinting the letter in the Revue Scientifique with all the solecisms, faults of grammar, and mistakes of idiom scored through or italicised, as if correcting a schoolboy's composition. The letter, as we now know, was written by Wöhler; it was unworthy of that calm and unimpassioned philosopher, and was, we may be sure, in after years regretted by him.

Whilst in Paris Gerhardt worked with Cahours, and after r84I many of his papers appeared in the Revue, more especially on didactic subjects connected with chemical philosophy.

In $184 \mathrm{r}$ he was appointed to succeed Balard at Montpellier, where he remained seven years. He continued to write for the Revue, but the results of his experimental work were, as a rule, sent to the Academy, and appeared in the Annales de Chimie. Almost at the outset of his career as a professor he was brought into conflict with Laurent, but the two men soon healed their differences, and to the great benefit of science and their own fame became firm friends and active co-workers until separated by Laurent's death in I853.

In 1848 Gerhardt returned to Paris, where he learnt to know Williamson, who was at that time studying mathematics under Comte. He had started the Comptes rendus des Travaux de Chimie in 1845 in association with Laurent, presumably to afford its editors a wider and more independent scope for the dissemination of their peculiar views than was possible to them in the 
Revue Scientifique. The journal had a somewhat chequered career; each year saw a change of publisher, and it ceased to appear in the troubled times of $\mathrm{r}_{55} \mathrm{I}$. He now started a school of practical chemistry at 29 Rue M. le Prince, where he had as pupils and collaborators, amongst others, Chancel, Chiozza, Pisani, and for a time August Kekulé. It was here, too, that he made his memorable researches on the organic anhydrides-the culminating point of his experimental work. Shortly before his death, in 1856 , at the age of forty, he was transferred to Strasburg, but beyond a couple of short papers published posthumously, nothing further appeared from his pen.

It would be impossible to do adequate justice, in an article of this kind, to the extraordinary value of Gerhardt's labours during the twenty short years of his ceaseless activity. His mind was continually at work upon the basic principles of theoretical chemistry, and his pen was never idle in expounding them. His wealth of ideas, the fruitfulness of his conceptions, his grasp, the range of his knowledge, and his logic and insight are simply astonishing. Much of his doctrine is now so woven into the structure of the science that to recall it all would seem to the student of to-day to savour of the commonplace. But what a catalogue it makes ! - the reform of the atomic weights, the unification of formulæ, the true conception of the molecule and the atom, constitutional formulæ, the principle of homology, the rôle of water in chemical change, the basicity of acids, and the nature and classification of salts. Such is the baldest summary of Gerhardt's influence on the philosophy of chemistry, as expounded in his critical papers and his various text-books, above all in his classical treatise on organic chemistry. His published papers number more than 100, almost exclusively on subjects of organic chemistry-essential oils, the alkaloids, amides, anilides, ureides, thiocyanates, mellonides, and lastly the acid anhydrides-coextensive, in fact, with the whole range of that section of the science. The admirable biography which we owe to M. Grimaux and the filial piety of M. Charles Gerhardt, jun., does full justice to these imperishable labours, and they are recalled in graceful and felicitous terms in the Conférence which M. Marc Tiffeneau delivered before the Chemical Society of France on the centenary of the birth of their illustrious author.

Charles Adolphe Wurtz was born at Strasburg on November 26, r817. He was the son of a Lutheran pastor in a small village near that city, and it was the intention of his father, who had inscribed his name at the Protestant seminary of theology, that he should follow his own profession. The boy, however, had been irresistibly attracted towards chemistry, and his inclination was strengthened by his association with Caillot, then professor at Strasburg, to whom eventually be became lecture-assistant. The father had little sympathy with the son's aspirations. In his judgment chemical science offered little or no prospect of a living, and accordingly the young Wurtz, to NO. 253 I, VOL. IOI] meet in some degree his parent's objections, applied himself to medicine and took his degree in that subject in 1843 . In the course of his studies he repaired to Giessen, then the Mecca of chemists, and worked under Liebig for about a year. This circumstance determined his career. In I844 he left Alsace to join Dumas, to whom he had been recommended by Liebig, and in the well-known laboratory in the Rue Cuvier he worked in company with Cahours, Melsens, Stas, Piria, and others, who became more or less eminent in that stirring and fruitful epoch.

Dumas's influence at that period was all-powerful in France, and Wurtz's rise was rapid. He was "chef des travaux chimiques" at the Ecole Centrale in 1845 , and in 1846 a member of the Faculty of Medicine. When Dumas became Minister of Agriculture and Commerce, after the, Revolution of $\mathrm{I} 848$, Wurtz succeeded him as professor of organic chemistry, becoming titular professor of mineral chemistry in 1853 in succession to Orfila and a line of such illustrious ancestors as Fourcroy and Vauquelin. Here he remained for twenty-one years, attracting to himself a body of active workers from all parts of Europe and-America by his power as a teacher, and by the enthusiastic energy with which he directed his school of research. In 1872 he was made professor of organic chemistry at the Sorbonne, a position created for him. He retired in $\mathrm{I} 882$ and died on May I2, I884.

During the half-century of Wurtz's scientific activity France passed through many political crises, which, no doubt, at times were not without influence on his position and prospects, but, on the whole, his career was far more placid and prosperous than that of his brilliant compatriot. Although practically contemporaries, Gerhardt was at the height of his fame when Wurtz was but little known outside Paris. To-day, indeed, the men seem to belong to a different age. By far the greater volume of Wurtz's work was published when Gerhardt had ceased to write. His earliest efforts were on inorganic subjects. He studied the acids of phosphorus and determined their basicities, which he afterwards confirmed by preparing their compound ethers; he discovered phosphoryl chloride and copper hydride, the first member of this class of substances to be made known, and noted the significance of the mode of its decomposition by hydrochloric acid in reference to the atomic constitution of elements in the free state.

But under the influence of Dumas he soon turned into the rapidly developing field of organic chemistry. His work on copper hydride led him to speculate on the constitution of Frankland's compound radicals, and to indicate the necessary existence of mixed radicals, such as methyl-ethyl, ethylamyl, etc. He discovered liquid cyanogen chloride and synthesised urethane, and prepared the cyanic and cyanuric ethers and the first of the compound ammonias-a subject brilliantly exploited by Hofmann a few years later. He prepared the compound ureas, established the triatomic character of 
glycerol, and predicted the existence of the diatomic alcohols, which he established by the discovery of glycol, glycollic acid, and a number of other derivatives. The theoretical deductions to which these researches gave rise led to a memorable controversy between the French and German schools, which greatly influenced the development of the conception of basicity, and the spread of Gerhardt's teaching of the true principles on which the formulation of organic compounds should be based.

In 1854 Wurtz isolated butyl alcohol (isopropyl carbinol) from the fusel oil of potato-spirit, and ten years later he added another term to this series of homologues by the preparation of his methylene hydrate, an isomeride of amyl alcohol discovered by Cahours. The mode of its resolution by heat into water and amylene led Wurtz to the study of abnormal vapour densities, as manifested by the thermal decomposition of phosphorus pentachloride, the hydrate and alcoholate of chloral, ammonium sulphydrate and chloride, etc. -an inquiry which brought him into conflict with Berthelot and Sainte-Claire Deville. His study of the action of hydrochloric acid on aldehyde led to the discovery of aldol, its polymerides, and other derivatives, which occupied much of his attention for several years.

The foregoing is a very incomplete summary of Wurtz's contributions to experimental chemistry contained within some 150 memoirs. His relation to his epoch has already been set forth in the admirable obituary notice by Friedel-himself an Alsatian-which appears in the Bulletin of the Chemical Society of France-a society of which Wurtz was one of the original founders, and which he consistently supported so long as he lived. A charming sketch of his life, work, and personality by his pupil and life-long friend, Prof. Armand Gautier, appeared in the Revue Scientifique of December 22-29, 19r 7 , written on the occasion of the celebration of his centenary. It affords a delightful picture of Wurtz as he appeared in his laboratory-the directing and dominant agency, primus inter pares, of a galaxy of collaborators such as Friedel, Caventou, Crafts, Louguinine, De Clermont, Salet, Naquet, Willm, Oppenheim, Lauth, Girard, Le Bel, Grimaux, Cleve, Chydenius, Tollens, Sell, Silva, Henninger, Maxwell Simpson, Hanriot, Franchimont, Echsner de Coninck, Richet, and van't Hoff, with Gautier.himself - all men who, stimulated by the example of their leader and influenced by his teaching, have contributed to fashion the edifice of modern chemistry.

Wurtz was a fine character-a man with a broad mind in a large and manly frame. He had all the qualities which attract men and fascinate youthcharm of manner, transparent integrity, generous impulses and a ready sympathy, an enthusiastic and loyal devotion to science, and a quick and whole-hearted appreciation of merit in those who sought to enlarge its boundaries. He was idolised by his students. As a lecturer he had much of the force and fire of his master, Dumas, the same NO. $253 \mathrm{I}$, VOL. IOI] gift of happy and graceful diction, the same clarity of thought, the same power of logical and lucid exposition. He had also, in no small measure, Dumas's facility of literary expression. No nobler tribute was ever penned than that paid by Wurtz, in the opening pages of his well-known Dictionnaire, to the genius and labours of Gerhardt and Laurent. M. Armand Gautier well applies to him the words which he himself used at the graveside of Dumas : "Votre grande figure n'est pas de celles qui puissent disparaître dans l'oubli. Votre souvenir se perpétuera, votre nom passera d'âge en âge. Vous vivrez par vos œuvres, par l'exemple que vous avez donne, par les productions immortelles et les qualités de votre esprit."

T. E. THORPE.

\section{ICE AND FLOWER EXPLORATION IN HIGH ASIA. ${ }^{1}$}

(I) THE indefatigable explorers of the glaciers of the Karakoram Himalayas, Dr. and Mrs. Workman, who have done more than any others to visit and map out the details of those vast ice-fields, give in the volume before us still another account of their travels and explorations in a new sector of these regions. As usual, in order to cover as much new ground as possible within the narrow summer limits in which travel was practicable, they formed separate and independent expeditions, although they combine their results in a single volume. At the present time, when so much is being written about the extension of women's sphere on account of the war, it is interesting to find abundant evidence here of the pre-zear exploits of a woman-pioneer in these Indian Alps, in fields usually regarded as the especial preserve of men, and of men of unusual nerve because of the physical perils to be encountered and overcome.

Mrs. Workman independently instituted and led the pioneer expedition to the hitherto unvisited Rose Glacier of Sia Chen, which is the longest nonpolar glacier in the world; Dr. Workman explored the Sher-pi-Gang and other glaciers and basins; and between them they' achieved the feat during two summers of mapping out nearly two thousand square miles of ice-field details for the first time. Although the journeys were performed in I9I I and I912, the exigencies of the war have prevented the publication before now; but as no one else has visited those regions since then, this delay in no way detracts from the interest and solid scientific value of the work accomplished and now given to the public.

A striking feature of the moraines in those remote regions was the great preponderance in them of sedimentary rocks at such an extreme altitude. The "black" moraines on the north, which must have been intensified in the snowy surroundings, were found to consist of hardened black shale and mixed with slabs of "a pure white ${ }^{1}(\mathrm{r})$ "Two Summers in the Ice-wilds of Eastern Karakoram : The Fxploration of Nineteen $\mathrm{Hu}$ dren Square Miles of Mountain and Flacier. Bv F. B. Workman and W. H. Workman. Pp. 296. (London: T. Fisher (2) "Onwin, Igr7.) Price $T$. 5.5 . net.

(2) "On the Eaves of the World." By Reginald Farrer. Vol. i., pp. xiit 3xr; Vol. ii., pp. viii +328 . (London: Edward Arnold igr 7 . Price, 2 vols. 3os. net. 